\title{
MODEL PEMBELAJARAN JIGSAW TERHADAP KEAKTIFAN BELAJAR SISWA DI MI AN-NAJAH SESELA
}

\author{
Aqodiah 1, Baiq Ida Astini ${ }^{2}$, \\ 1,2 Program Studi PGMI, Universitas Muhammadiyah Mataram, Indonesia \\ aqodiah@gmail.com ${ }^{1}$, astinibaiqida@gmail.com ${ }^{2}$
}

\section{INFO ARTIKEL}

\section{Riwayat Artikel:}

Diterima: 03-03-2020

Disetujui: 30-04 -2020

\section{Kata Kunci: \\ Model Pembelajaran, \\ Kooperatife, \\ Jigsaw.}

\section{Keywords:}

Models of learning,

Cooperatife,

Jigsaw.

\begin{abstract}
Abstrak: Keaktifan siswa dalam proses belajar mengajar merupakan tanggung jawab seorang guru, guru dituntut untuk menggunakan berbagai model dalam proses pembelajaran di kelas dengan harapan supaya kelas tidak monoton dengan ceramah, salah satu model pembelajaran yang ditawarkan adalah Jigsaw. Jigsaw merupakan model pembelajaran yang dapat memacu keaktifan siswa dalam belajar. Penelitian ini menggunakan penelitian Tindakan Kelas yang dilakukan dalam 2 siklus dimana tujuan penelitian ini adalah memberikan solusi bagi guru dalam menerapkan model pembelajaran Jigsaw pada siswa kelas VB MI An-Najah Sesela. Pengumpulan data diperoleh dengan lembar observasi guru dan siswa. Hasil penelitian ini menunjukan adanya Peningkatan keaktifan belajar siswa pada siklus I menunjukan kriteria keaktifan belajar siswa cukup nampak persentasi keaktifan belajar siswa $54 \%$, meskipun pada pelaksanaan pada siklus I sudah cukup nampak namun masih banyak hal yang harus diperbaiki pada siklus I. Selanjutnya siklus II peneliti mendapatkan peningkatan. Pada pelaksanaan siklus II memperoleh persentase keaktifan belajar siswa 79\% dengan kriteria keaktifan belajar sangat nampak, Terlihat sangat jelas pada siklus II mengalami peningkatan. Hasil ini menunjukan bahwa penerapan model pembelajaran jigsaw dapat meningkatkan keaktifan belajar akidah akhlak pada siswa kelas V B MI An-Najah Sesela.
\end{abstract}

ABSTRAK

\begin{abstract}
The activity of students in the teaching and learning process is the responsibility of a teacher, teachers are required to use various models in the learning process in class with the hope that the class is not monotonous with the lecture, one of the learning models offered is Jigsaw. Jigsaw is a learning model that can stimulate students ' active learning. This research uses class action research conducted in 2 cycles where the purpose of this research is to provide solutions for teachers to implement Jigsaw learning models in VB MI An-Najah Sesela class students. Data collection is obtained with teacher and student observation sheets. The results of this study showed that the increase in student learning activity in cycle I showed the criteria of student learning active enough to see a percentage of the student's learning activity at 54\%, although on the implementation of cycle I was quite visible but still a lot of things to be improved on the I cycle. Next cycle II researchers get increased. In the implementation of the cycle II gained the percentage of active students learning 79\% with the criteria of active learning is very visible, very clear in cycle II experienced improvement. This results showed that the application of the Jigsaw learning model can improve the activity of learning the morality of students in class V B MI An-Najah Sesela.
\end{abstract}

\section{A. PENDAHULUAN}

Undang-undang Republik Indonesia Nomor 20 Tahun 2003 tentang Sistem Pendidikan Nasional Bab 1 Pasal 1 dinyatakan bahwa pendidikn adalah usaha sadar dan terencana untuk mewujudkan suasana belajar dan proses pembelajaran, agar peserta didik secara aktif mengembangkan potensi dirinya, untuk memiliki kekuatan spiritual keagamaan, pengendalian diri, kedisiplinan, kecerdasan akhlak mulia, serta keterampilan yang diperlukan dirinya, masyarakat, dan Negara. ${ }^{1}$ Pendidikan menjadi salah satu

\footnotetext{
1 Permendiknas ,"SI DAN SKL" (Jakarta: Sinar Grafika, 2006), hal.2
}

komponen penting untuk mencerdaskan anakanak bangsa. Sehingga dalam proses kegiatan pendidikan harus dilaksanakan secara terarah.

Dalam proses belajar mengajar, guru mempunyai tugas untuk mendorong, membimbing, dan memberi fasilitas belajar bagi siswa untuk mencapai tujuan. ${ }^{2}$ Guru mempunyai tanggung jawab untuk melihat segala sesuatu yang terjadi dalam kelas untuk membantu proses perkembangan siswa. Salah satu dari tugas guru yaitu membantu perkembangan aspek-aspek pribadi sperti sikap, nilai-nilai, dan penyesuaian diri. Demikianlah, dalam proses belajar mengajar

\footnotetext{
2 Slameto, "Belajar dan Faktor-Faktor Yang Mempengaruhinya" (Jakarta: PT Reneka Cipta: 2010), hal. 97
} 
guru tidak terbatas sebagai penyampai ilmu pengetahuan akan tetapi lebih dari itu, ia bertanggung jawab akan keseluruhan perkembangan kepribadian siswa. Ia harus mampu menciptakan proses belajar yang sedemikian rupa sehingga dapat merangsang siswa untuk belajar secara aktif dan dinamis dalam memenuhi kebutuhan dan menciptakan tujuan.

Salah satu bidang studi yang termaksud dalam pendidikan agama adalah Akidah Akhlak. Menurut bahasa, akidah berasal dari bahasa Arab: 'aqada-ya'qidu-uqdatan-wa 'aqidatan. Artinya ikatan atau perjanjian, maksudnya sesuatu yang menjadi tempat bagi hati dan hati nurani terikat kepadanya3 ${ }^{3}$. Secara istilah menurut Abu Bakar Jabir Al-Jazairi Aqidah adalah sejumlah kebenaran yang dapat diterima secara umum (aksioma) oleh manusia berdasarkan akal, wahyu dan fitrah. (Kebenaran) itu dipatrikan (oleh manusia) didalam hati (serta) diyakini kesahihan dan kebenarannya (secara pasti) dan ditolak segala sesuatu yang bertentangan dengan kebenaran itu.

Dalam Bahasa Arab Akhlak di sebut (khuluq) yang artinya budi pekerti. Imam Al-Ghazali mengatakan akhlak adalah daya kekuatan (sifat) yang tertanam dalam jiwa dan mendorong perbuatan-perbuatan spontan tanpa memerlukan pertimbangan pikiran. Jadi, akhlak merupakan sikap yang melekat pada diri seseorang dan secara spontan diwujudkan dalam tingkah laku dan perbuatan. ${ }^{4}$ Tujuan pendidikan agama adalah agar siswa memahami, menghayati, meyakini dan mengamalkan ajaran Agama Islam sehingga menjadi manusia muslim yang beriman, bertakwa kepada Allah SWT, dan berakhlak mulia. Akhlak atau prilaku yang mulia tentu tidak muncul begitu saja, ia harus di bentuk semenjak dini sejak masa anak-anak, agar kelak dimasa yang akan datang dapat menjadi anak yang ber-akhlakul karimah dan bertingkah laku dengan baik.

Adapun tujuan pembelajaran akidah akhlak yaitu: 1) Memberikan pengetahuan, penghayatan dan keyakinan kepada peserta didik akan hal-hal yang harus diimani, sehingga tercermin dalam sikap dan tingkah lakunya. 2) Memberikan pengetahuan, penghayatan dan kemauan kuat dalam mengamalkan Akhlak yang baik, dan menjauhi Akhlak yang buruk dalam hubungan dengan Allah, dengan dirinya sendiri, dengan sesama manusia, maupun dengan lingkunganya.

\footnotetext{
${ }^{3}$ Sukarta "Kuliah Akidah" (Mataram: Lembaga Pengkajian dan Pengalaman Islam, 2015), hal.4

${ }^{4}$ Rosihon Anwar "Akidah Akhlak" (Bandung: CV Pustaka Setia, 2014), hal. 205
}

Dari latar belakang diatas, penulis tertarik mengkaji tentang pembelajaran jigsaw terhadap keaktifan belajar siswa di MI An-Najah Sesela Gunungsari Lombok Barat

\section{B. KAJIAN TEORI}

\section{Pengertian Pembelajaran}

Pembelajaran merupakan proses intraksi peserta didik dengan pendidik dan sumber belajar pada suatu lingkungan belajar yang meliputi guru dan siswa yang saling bertukar informasi. ${ }^{5}$ Menurut Gagne belajar merupakan kegiatan yang kompleks. Hasil belajar berupa kapabilitas. Setelah belajar orang memiliki keterampilan, pengetahuan, sikap, dan nilai. Timbulnya kapabilitas tersebut adalah dari stimulasi yang berasal dari lingkungan, dan proses kognitif yang dilakukan oleh pembelajar. Dengan demikian, belajar adalah seperangkat proses kognitif yang mengubah sifat stimulasi lingkungan, melewati pengolahan informasi, menjadi kapabilitas baru. ${ }^{6}$

\section{Model Pembelajaran Jigsaw}

\section{a) Pengertian Model Pembelajaran}

Istilah Model Pembelajaran memiliki makna yang lebih luas daripada strategi, metode, atau prosedur. Model pembelajaran mencakup suatu pendekatan pembelajaran yang luas dan menyeluruh. Model pembelajaran pada dasarnya merupakan bentuk pembelajaran yang tergambar dari awal sampai akhir yang disajikan secara khas oleh guru. Model pembelajaran ibarat bungkus atau bingkai dari penerapan suatu pendekatan, sterategi, metode, teknik, dan taktik pembelajaran model pembelajaran dapat menggunakan sejumlah keterampilan metodologis dan prosedural. ${ }^{7}$

Soekamto mengemukakan model pembelajaran adalah kerangka konseptual yang melukiskan prosedur sitematis mengorganisasikan pengalaman belajar untuk mencapai tujuan belajar tertentu dan berfungsi sebagai pedoman bagi para perancang pembelajaran dan para pengajar merencanakan aktivitas belajar mengajar. ${ }^{8}$

\section{b) Metode Jigsaw}

Jigsaw adalah tipe pembelajaran kooperatif yang dikembangkan oleh Elliot Aronson's. Model

\footnotetext{
5 Ahmad Susanto, "Teori Belajar Dan Pembelajaran Di Sekolah Dasar" (Jakarta : PRENADAMEDIA GROUP),Hal.18

${ }^{6}$ Mudjiono,"Belajar Dan Pembelajaran" (Jakarta : Rineka Cipta, 2009), Hal.7

7 Agus Suprijono, "Model-Model Pembelajaran Emansipatoris" (Yogyakarta: Pustaka Pelajar, 2016),hal.51

IIbid,hal 53
} 
pembelajaran di desain untuk meningkatkan rasa tanggung jawab siswa terhadap pembelajaran sendiri dan juga pembelajaran orang lain. Siswa tidak hanya mempelajari materi yang diberikan, tetapi juga harus siap memberikan dan mengajarkan materi tersebut kepada kelompoknya, sehingga baik kemampuan secara kognitif maupun sosial siswa sangat diperlukan. Model pembelajaran jigsaw ini dilandasi oleh teori belajar humanistik, karena teori belajar humanistik menjelaskan bahwa pada hakikatnya setiap manusia adalah untuk memiliki potensi individual dan dorongan internal untuk berkembang dan menentukan prilakunya.

Model pembelajaran Jigsaw merupakan model pembelajaran yang melibatkan siswa belajar dalam kelompok kecil yang terdiri atas 4-6 orang dengan memperhatikan keheterogenan, bekerja sama positif dan setiap anggota bertangung jawab untuk mempelajari masalah tertentu dari materi yang diberikan dan menyampaikan materi tersebut kepada anggota kelompok yang lain. ${ }^{9}$

\section{c) Langkah-langkah Pembelajaran dengan Metode Jigsaw}

Langkah-langkah Pembelajaran Jigsaw diantaranya adalah; a) Membentuk kelompok heterogen yang beranggotakan 4-6 orang, b) Tiap orang dalam kelompok diberi sub topik yang berbeda, c) Setiap kelompok membaca dan mendiskusikan sub topik masing-masing dan menetapkan anggota ahli yang akan bergabung dalam kelompok ahli, d) Anggota ahli dari masing-masing kelompok berkumpul dan mengintegrasikan semua sub topik yang telah dibagikan sesuai dengan banyaknya kelompok, e) Kelompok ahli berdiskusi untuk membahas topik yang diberikan dan saling membantu untuk menguasai topik tersebut, f) Setelah memahami materi, kelompok ahli menyebar dan kembali ke kelompok masing-masing, kemudian menjelaskan materi kepada rekan kelompoknya, g) Tiap kelompok mempresentasikan hasil diskusi, h) Guru memberikan tes individual pada akhir pelajaran tentang materi yang telah didiskusikan, i) Siswa mengerjakan tes individu atau kelompok yang mencakup semua topic, j) Siswa mengerjakan tes individu atau kelompok yang mencangkup semua topik. ${ }^{10}$

\footnotetext{
9 Jumanta Hamdayana,"Model Dan Metode Pembeljaran Kreatif Dan Berkarakter" (Bogor : Ghalia Indonesia, 2014). hal.87

10 Trianto Ibnu Badar "Mendesain Model Pembelajaran Inovatif, Progresif Dan Kontekstual" (Jakarta: Prenada media Group, 2015), hal.123
}

\section{d) Kelebihan Model Pembelajaran Jigsaw}

$\begin{array}{lll}\text { Kelebihan dalam penggunaan metode } & \text { metom } \\ \text { pembeajaran jigsaw adalah } & \text { sebagai }\end{array}$

berikut :

a) Mempermudah pekerjaan guru dalam mengajar, karna sudah ada kelompok ahli yang bertugas menjelaskan materi kepada rekan-rekannya.

b) Pemerataan pengusaan materi dapat dicapai dalam waktu yang lebih singkat

c) Metode pembelajaran ini dapat melatih siswa untuk lebih aktif dalam berbicara dan berpendapat. ${ }^{11}$

\section{e. Kekurangan Model Pembelajaran Jigsaw}

Beberapa hal yang bisa menjadi kelemahan aplikasi model ini di lapangan, menurut Roy Killen adalah sebagai berikut.

a) Prinsip utama pembelajaran ini adalah 'peer teaching' pembelajaran oleh teman sendiri, akan menjadi kendala karena perbedaan persepsi dalaam memahami konsep yang akan didiskusikan bersama siswa lain.

b) Apabila siswa tidak memiliki rasa percaya diri dalam berdiskusi menyampaikan materi pada teman.

c) Record siswa tentang nilai, kepribadian, perhatian siswa harus sudah dimiliki oleh guru dan biasanya butuh waktu yang sangat lama untuk mengenali tipe-tipe siswa dalam kelas tersebut.

d) Butuh waktu yang cukup dan persiapan yang matang sebelum model pembelajaran ini bisa berjalan dengan baik.

e) Aplikasi metode ini pada kelas yang lebih besar (lebih dari 40 siswa) sangatlah sulit.

Dalam penerapannya sering dijumpai beberapa permasalahan, diantaranya sebagai berikut; a) Siswa yang aktif akan lebih mendominasi diskusi, dan cendrung mengontrol jalannya diskusi.b) Siswa yang memiliki kemampuan membaca dan berpikir rendah akan mengalami kesulitan untuk menjelaskan materi apabila ditunjuk sebagai tenaga ahli.Siswa yang cerdas cendrung merasa bosan. d) Pembagian kelompok yang tidak heterogen, dimungkinkan kelompok yang anggotanya lemah semua. e) Penugasan anggota kelompok untuk menjadi tim

11 Jumanta Hamdayama "Model Dan Metode Pembelajaran” (Bogor: Ghalia Indonesia ,2014),hal.89 
ahli sering tidak sesuai antara kemampuan dengan kompetensi yang harus dipelajari. f) Siswa yang tidak biasa berkompetisi akan kesulitan untuk mengikuti proses pembelajaran.

\section{METODE PENELITIAN}

Dalam penelitian ini, peneliti menggunakan desain Penelitian Tindakan Kelas (PTK). PTK merupakan susatu penelitian yang dilakukan oleh guru dikelasnya sendiri melalui refleksi diri dengan tujuan umtuk memperbaiki kinerjanya sehingga hasil belajar siswa meningkat. ${ }^{12}$

\section{Lokasi Penelitian}

Penelitian PTK ini akan dilaksanakan di MI An-Najah Desa Sesela pada semester genap (semester 2) Tahun Ajaran 2019/2020

\section{Subjek Penelitian}

Subjek penelitian ini adalah siswa kelas V B di MI An-Najah Desa Sesela dengan jumlah siswa 19 orang yang terdiri dari 13 orang siswa laki-laki dan 6 orang siswa perempuan. Objek penelitian ini adalah penerapan model pembelajaran jigsaw.

\section{Rencana Tindakan}

PTK merupakan sebuah bentuk penelitian yang bersifat relektif, dengan teknik participant observation supaya dapat memperbaiki dan meingkatkan praktik-praktik pembelajaran dalam kelas secara professional.

Penelitian tindakan kelas ini terdiri dari beberapa siklus dan masing-masing siklus terdiri dari empat tahap yaitu: a) merencanakan. b)melakukan tindakan. c) observasi. d) melakukan refleksi. ${ }^{13}$

Skema Siklus Penelitian Tindakan Kelas (PTK)

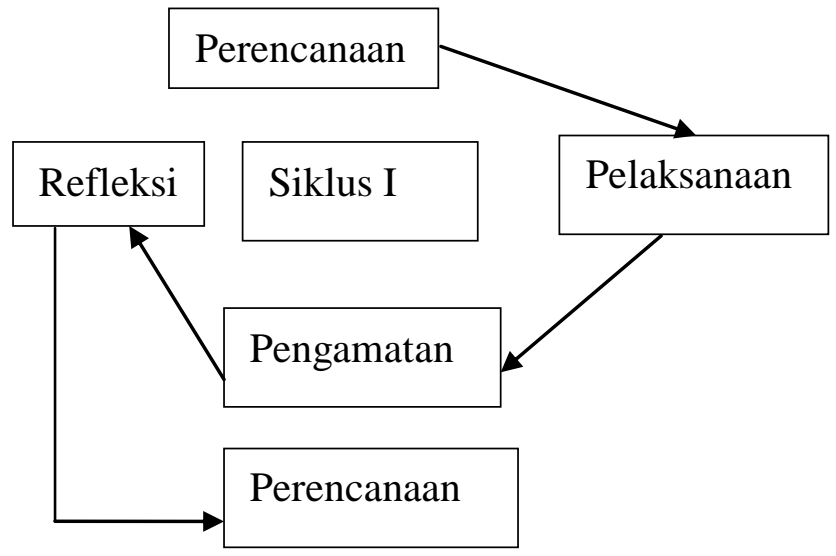

12 Zainal Aqib, "Penelitian Tindakan Kelas", (Bandung: CV Yrama Widya, 2010), hal.3

13 Iskandar, "Penelitian Tindakan Kelas" (Jakarta : Gaung Persada, 2011),hal.113

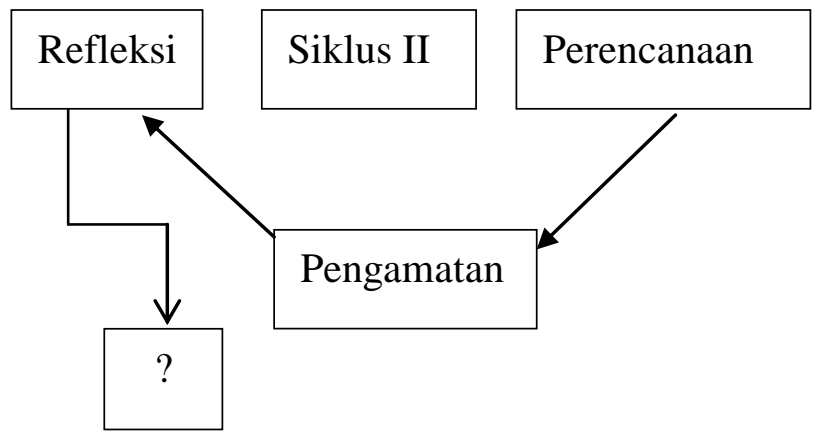

Adapun rincian dari tahapan yang terdapat dalam siklus Penelitian Tindakan Kelas.

\subsection{Tahap perencanaan} meliputi

Pada tahap ini, kegiatan yang dilaksanakan

a. Menentukan materi yang akan digunakan

b. Guru bersama peneliti menyusun rencana pelaksanaan pembelajaran (RPP) untuk melaksanakan metode jigsaw dan memperhatikan materi pelajaran

c. Menyiapkan lembar kerja siswa

d. Menyiapkan bahan atau alat yang diperlukan selama melakukan tindakan

e. Menyiapkan tes evaluasi untuk mengetahui tingkat pemahaman siswa terhadap materi yang dipelajari.

f. Menyiapkan lembar observasi aktivitas guru dan sissa untuk mengetahui kondisi pembelajaran siswa ketika menerapkan model jigsaw.

\subsection{Pelaksanaan tindakan}

Tindakan yang dilakukan peneliti yang direncanakan dalam dua siklus setiap siklus dilaksanakan dalam beberapa kali pertemuan. Setiap siklus pembelajaran menerapkan model jigsaw dengan pembelajaran akidah akhlak. Jika ternyata tindakan perbaikan pada siklus pertama belum berhasil menjawab masalah, maka dilaksanakan siklus berikutnya dengan langkahlangkah pembelajaran yang sama namun dengan indikator yang berbeda. Siklus I, siklus II dilaksanakan sesuai dengan RPP yang telah disusun. ${ }^{14}$

\subsection{Observasi/ pengamatan}

Observasi yaitu, melakukan pengamatan secara langsung ke objek penelitian untuk melihat dari dekat kegiatan yang dilakukan. Pada tahap ini peneliti melakukan pengamatan dan mencatat semua hal yang diperlukan dan terjadi Selama pelaksanaan tindakan berlangsung. Pengumpulan data ini dilakukan dengan menggunakan format

14 Ibid, hal.115 
observasi/ penelitian yang telah disusun..$^{15}$ Melalui pengumpulan data yang berupa informasi, observasi dapat mengetahui dan mencatat tentang kekurangan dan kelebihan proses pembelajaran yang dilakukan oleh guru sesuai dengan prencanaan tindakan yang menggunakan model pembelajaran jigsaw pada siswa kelas V di MI Annajah Desa Sesela.

\subsection{Refleksi}

Refleksi yaitu, kegiatan untuk mengemukakan kembali apa yang sudah terjadi. Jadi penelitian melalui refleksi ini melakuka renungan tentang model pembelajaran jigsaw sudah mampu atau belum, meningkatkan keaktifan belajar siswa selama dalam tindakan yang sesuai perencanaan. 16 Pada tahap ini peneliti memperhatikan hasil observasi dan menjadikannya sebagai bahan pertimbangan untuk perencanaan siklus pembelajaran berikutnya. Refleki bertujuan untuk melihat apakah pada siklus 1 model pembelajaran jigsaw sudah dilakukan secara efektif atau belum. Serta mengethui letak kelemahan dan kekurangan dari hasil tindakan. Refleksi dapat melakukn perbaikan pada tindakan berikutnya. Indikator berakhirnya siklus adalah adalah peningkatan keaktifan belajar yang dicapai siswa dengan capaian minimal sekurang-kurangnya $80 \%$ siswa telah mencapai nilai tuntas (diatas minimal).

\section{Instrumen Penelitian}

Pengumpulan data dilakukan oleh guru sebagai peneliti selama proses pelaksanaan tindakan. Data dapat dikumpulkan dengan berbagai teknik seperti Tes, observasi, dokumentasi, angket dan sebagainya. Observasi merupakan salah satu teknik pengumpulan data yang sangat menentukan dalm PTK.

\subsection{Tes}

Tes adalah suatu alat atau prosedur yang sistematis dan objektif untuk memperoleh data atau keterangan yang diinginkan tentang seseorang dengan cara yang boleh dikatakan tepat dan cepat. Tes dugunakan untuk mengukur pencapaian seseorang setelah mempelajari sesuatu. Tes tersebut diberikan kepada siswa guna mendapatkan data kemampuan siswa tentang materi pelajaran akidah akhlak. Tes yang digunakan adalah butiran soal yang dilaksanakan pada saat pra tindakan maupun akhir tindakan, yang nantinya hasil tes ini akan diolah untuk mengetahui tingkat keberhasilan siswa dalam

15 Wina Sanjaya, Penelitian Pendidikan Jenis, Metode, Dan Prosedur (Jakarta : Kencana, 2013, Hal.149

16 Ibid, 149 proses pembelajaran dengan menerapkan model pembelajaran kooperatif tipe jigsaw pada mata pelajaran akidah akhlak. Tes yang digunakan pada penelitian ini adalah: ${ }^{17}$

a) Tes pada awal penelitian (pra text), dengan tujuan untuk mengetahui pemahaman siswa tentang materi yang akan diajarkan.

b) Tes pada setiap akhir tindakan (post text), bertujuan untuk mengetahui peningkatan pemahaman dan prestasi belajar siswa terhadap materi yang diajarkan dengan menerapkan model pembelajaran kooperatif tipe jigsaw untuk meningkatkan keaktifan belajar akidah akhlak siswa kelas V di MI AnNajah Desa Sesela Kecamatan Gunungsari Kabupaten Lombok Barat.

\subsection{Observasi}

Observasi adalah kegiatan pengamatan (pengambilan nilai) untuk memotret seberapa jauh efek tindakan yang telah mencapai sasaran. Efek dari suatu intervensinterus dimonitor secara reflektif. 18 Observasi yang digunakan dalam penelitian ini adalah observasi langsung karena selain peneliti terlibat secara langsung di dalamnya peneliti juga mendapatkan data tentang aktivitas siswa dan guru saat proses pembelajan.

\subsection{Dokumentasi}

Dokumentasi merupakan suatu proses pengumpulan data dengan cara mencari data-data tertulis seagai bukti penelitian. Dokumentasi adalah mencari data mengenai hal-hal atau variable yang berupa catatan, transkip, buku, surat, majalah, prasasti, notulen rapat, lengger agenda, dan sebagainya. Metode dokumentasi digunakan untuk memperoleh data tentang keadaan objek MI An-najah Desa Sesela Gunung Sari seperti sejarah berdirinya, visi misi, keadaan peserta didik, dan keadaan sarana dan prasarana.

\subsection{Angket}

Angket atau kuesioner adalah suatu daftar yang berisikan rangkaian pertanyaan mengenai suatu masalah atau bidang yang akan diteliti. Untuk memperoleh data, angket dalam penelitian ini digunakan untuk mngukur minat belajar siswa dan dibagikan kepada semua siswa yang mengikuti pembelajaran akidah akhlak yaitu siswa kelas $1 \mathrm{MI}$ An-najah Desa Sesela. Data dari angket yang digunakan untuk memperoleh data yang telah diperoleh berdasarkan lembar observasi.

\section{Analisis Data}

Untuk menentukan skor yang diperoleh guru dan siswa skor setiap individu tergantung banyak

\footnotetext{
17 Ngalim Purwanto, "Prinsip-Prinsip Dan Teknik Evaluasi Pengajaran” (Bandung : PT Remaja Rosdakarya, 2012), Hal.28

18 Suharsimi Arikunto,Penelitian Tindakan Kelas, (Jakarta: PT Bumi Aksara, 2012), hal 127
} 
perilaku yang dilakukan siswa dari sejumlah indikator yang diamati dengan ketentuan skor sebagai berikut:

a) Skor 1 diberikan jika tidak nampak 0\%-25\%

b) Skor 2 diberikan jika kurang nampak 25\%-50\%

c) Skor 3 diberikan jika cukup nampak 50\%-75\%

d) Skor 4 diberikan jika sangat nampak 75\%$100 \%$

$$
\mathrm{NA}=\frac{\text { 표 }}{B} \times 100
$$

Keterangan :
NA : Nilai Akhir
A : Skor perolehan
B : Skor maksimal

Penilaian diberikan dengan tanda cek $(\sqrt{ })$ pada kolom sesuai.

\section{HASIL DAN PEMBAHASAN}

\section{Hasil Penelitian Penerapan Model Pembelajaran Jigsaw Terhadap Keaktifan Belajar Akidah Akhlak Siswa Kelas V B}

Sesuai dengan permasalahan yang muncul pada pengamatan awal yaitu tentang keaktifan belajar siswa kelas V B pada mata pelajaran akidah akhlak. Maka peneliti ingin menggunakan model pembelajaran jigsaw untuk meningkatkan keaktifan belajar siswa. Pada siklus 1 peneliti bersama guru membuat kesepakatan yakni peneliti diberi wewenang sebagai guru mata pelajaran akidah akhlak. Penelitian ini dilaksanakan dalam dua siklus yang dilaksanakan pada hari sabtu tanggal 11 Mei 2019 selama 2 x 35 menit dengan membahas materi tentang akhlak tercela dengan menggunakan model pembelajaran jigsaw. 19 Pertemuan kedua dilaksanakan pada hari sabtu tanggal 18 Mei 2019 dengan alokasi waktu selama 2 x 35 menit dengan membahas secara singkat materi sebelumnya. Adapun langkah-langkah pelaksanaan siklus I sebagai berikut:

\subsection{Siklus 1}

Agar penelitian ini bisa berjalan dengan baik dan memperoleh hasil yang diharapkan maka perlu beberapa penerapan yang dipersiapkan dalam siklus 1 sebagai berikut:

\section{a. Tahap Perencanaan}

1) Menyiapkan rencana pelaksanaan pembelajaran (RPP) siklus 1 pertemuan pertama dan kedua telah disetujui oleh guru mata pelajaran akidah akhlak kelas $\mathrm{V}$ B, mengingat penelitian tindakan yang

19 Penerapan Model Pembelajaran Jigsaw Pada Siklus I Dan II Pada Tanggal 11 Dan 18 Mei 2019 dilakukan adalah kolaborasi antara guru mata pelajaran akidah akhlak dan peneliti agar bisa meminimalisir kekurangan yang terjadi. ${ }^{20}$

2) Tersedianya sumber atau bahan yang digunakan dalam proses pembelajaran jigsaw.

3) Tersedianya lembar kerja siswa (LKS) pada pertemuan pertama dan kedua dan kunci jawaban pertemuan pertama dan kedua.

4) Tersedianya lembar observasi yang terdiri dari lembar aktivitas mengajar guru dan lembar observasi aktivitas belajar siswa untuk mengetahui kondisi pembelajaran siswa ketika proses pembalajaran berlangsung.

\section{b. Tahap Pelaksanaan Tindakan}

Hal yang dilakukan pada tahap pelaksanaan tindakan ini, yaitu melaksanakan kegiatan belajar mengajar di kelas sesuai dengan rencana yang telah dituangkan dalam skenario pembelajaran. Kegiatan yang dilaksanakan pada tahap ini adalah pelaksanaan tindakan dengan penerapan model pembelajaran jigsaw pada mata pelajaran akidah akhlak siswa kelas V B MI An-Najah Desa Sesela. Untuk melihat tingkat aktivitas belajar siswa dan aktivitas mengajar guru dalam proses pembelajaran pada tahap pelaksanaan adalah sebagai berikut:

\section{1) Kegiatan Awal}

Guru mengawali kegiatan dengan mengucapakan salam pembuka, dimana siswa menjawab salam dengan semangat dan di ikuti dengan aktivitas berdo'a yang dipimpin oleh ketua kelas. Selanjutnya mengecek kehadiran siswa. Guru melakukan tepuk semangat supaya siswa bergairah ketika proses belajar dan menumbuhkan minat belajar agar aktif dalam belajar dengan cara memberikan motivasi kepada seluruh siswa tentang pentingnya belajar agar siswa menjadi termotivasi dalam belajar dengan baik dan serius supaya menambah ilmu dan wawasan mereka. Kemudian guru menanyakan siswa materi yang sudah diplajari. Setelah itu guru menyampaikan tujuan pembelajaran yang disampaikan oleh guru. Kemudian guru menanyakan kesiapan belajar berkaitan dengan materi yang akan disampaikan.

\section{2) Kegiatan Inti}

Guru menjelaskan materi tentang akhlak tercela dan akibatnya sambil menanyakan kembali materi yang belum dipahami. Selanjutnya, guru membentuk kelompok berdasarkan tingkat kemampuan dan jenis kelamin yang berbeda-beda,

${ }^{20}$ Iskandar, "Penelitian Tindakan Kelas" (Jakarta: Gaung Persada, 2011), hal.67 
siswa dibagi menjadi 3 kelompok setiap kelompok terdiri dari 5 orang kemudian guru memberikan lembar kerja siswa (LKS) pada masing-masing kelompok dan siswa bersama kelompoknya menjawab pertanyaan yang terdapat dalam LKS dalam bimbing guru. Selanjutnya, guru meminta perwakilan pada tiap-tiap kelompok untuk memaparkan hasil diskusinya

\section{3) Kegitan Akhir (Penutup)}

Guru mengadakan kegiatan Tanya jawab kepada siswa terkait materi yang telah dipelajari. Mengacu kepada kegiatan Tanya jawab, guru bersama siswa membuat rangkuman tentang materi yang telah dipelajari. Selanjutnya, guru memberi saran kepada siswa untuk rajin belajar.

\section{c. Tahap Pengamatan}

\section{Observasi Siswa}

Kegiatan pada tahap ini, dilakukan observer terhadap kegiatan belajar siswa di dalam kelas yang dilakukan oleh Amanda sebagai teman sejawat dari peneliti sebagai observer II yang mengamati aktivitas belajar siswa yang telah disediakan dan disosialisasikan cara penggunaan sebelumnya. Selain menggunakan lembar observasi aktivitas belajar siswa, peneliti juga menggunakan kamera untuk mendokumentasikan aktivitas siswa saat kegiatan belajar siswa berlangsung.

\section{Observasi Aktivitas Guru}

Kegiatan pada tahap ini, dilakukan observasi terhadap aktivitas mengajar guru didalam kelas oleh guru mata pelajaran akidah akhlak kelas V B MI An-Najah Desa Sesela Gunung Sari yaitu, Bapak H. Ahmad Sanusi, S.Pd selaku observer pertama yang mengamati aktivitas mengajar guru yang telah disediakan dan disosialisasikan cara penggunaannya.

\section{d. Refleksi}

Setelah pertemuan kedua di siklus I, peneliti dan guru melakukan refleksi terhadap pelaksanaan tindakan pada siklus I kesimpulan yang diperoleh bahwa a) Antusiasme siswa dalam mengikuti pembelajaran masih kurang b) Masih terlihat adanya siswa yang kuramg aktif dan terkesan bermain pada saat kegiatan belajar mengajar, Guru kurang memberikan bimbingan kepada siswa saat mengerjakan soal LKS, dan Siswa masih kurang menguasai materi seingga dalam diskusi siswa kesulitan dalam menjawab

\subsection{Siklus II.}

Pada siklus II dilakukan pembelajaran untuk memperbaiki siklus I. Proses belajar mengajar pada siklus II dilaksanakan pada hari sabtu tanggal 18 Mei 2019 materi akhlak tercela menjelaskan macam-macam akhlak tercela dan akibat buruk dari akhlak tercela itu sendiri. dan menjelaskan sedikit tentang materi yang akan didiskusikan oleh siswa dan langsung memberikan Lembar kerja siswa.

\section{a. Tahap Perencanaan}

Tahap perencanaan pada siklus II sama dengan tahap siklus I.

\section{b. Tahap Pelaksanaan Tindakan}

Pada dasarnya pelaksanaan pembelajaran pada siklus II ini sama dengan siklus I, namun ada sedikit perubahan untuk memperbaiki siklus I yang kurang berhasil, karena proses pembelajaran pada siklus II ini dilaksanakan berdasarkan hasil refleksi siklus I.

\section{c. Tahap pengamatan \\ 1) Observasi siswa}

Sama halnya dalam observasi siswa pada siklus I, dalam observasi siswa yang diamati adalah kegiatan belajar siswa, terutama saat guru menjelaskan materi. Observasi kegiatan belajar siswa dimaksud untuk mengetahui sejauah mana solusi dari hasil refleksi pada siklus I. Dalam sikuls II siswa sudah mulai berdiskusi bersama teman kelompoknya dengan pengawasan dari guru.

\section{2) Observasi Guru}

$\begin{array}{rrr}\text { Dalam } & \text { siklus II peneliti juga } \\ \text { melakukan } & \text { observasi } & \text { terhadap }\end{array}$
keterlaksanaan model pembelajarn jigsaw guru sama halnya yang dilakukan peneliti pada siklus I. Pada siklus II, guru sudah mencoba memperbaiki kekurangan di siklus I. Pelaksanaan kegiatan observasi aktivitas mengajar guru masih diamati oleh Bapak H. Ahmad Sanusi S.Pd yang bertindak sebagai observer I.

Berdasarkan hasil akhir siklus II di atas diperoleh persentase keaktifan belajar siswa 91\%, berdasarkan persentase tersebut dapat diketahui pada siklus II siswa kelas V B telah terlihat aktif dalam belajar. Dengan demikian dapat dikatakan bahwa metode pembelajaran Jigsaw mampu meningkatkan keaktifan belajar siswa di kelas VB MI An-Najah desa sesela. 


\section{Penerapan Metode Jigsaw pada Mata Pelajaran Akidah Akhlak \\ Metode jigsaw diterapkan di kelas V B} dengan jumlah siswa sebanyak 19 orang. Sebelum proses pembelajaran, siswa dibagi menjadi 3 kelompok. Pembentukan kelompok dilakukan oleh peneliti. Hal ini dilakukan untuk menjamin tingkat heterogen dalam setiap kelompok, supaya didalam kelompok terdapat siswa yang berkemampuan tinggi, sedang dan rendah. Pelaksanaan pembelajaran dilaksanakan dengan menggunakan dua siklus.

Pada kegiatan awal peneliti menyampaikan tujuan pembelajaran yang ingin dicapai. ${ }^{21} \mathrm{Hal}$ ini dilakukan agar siswa mengetahui apa yang akan mereka pelajari, sehingga siswa akan terarah, termotivasi dan terpusat perhatiannya dalam belajar. Peneliti juga mempertegas dalam menyampaikan materi.

Pada kegiatan inti, peneliti menjelaskan materi dengan tanya jawab dan menerapkan metode jigsaw kemudian peneliti menbagi siswa menjadi 3 kelompok secara heterogen. kemudian peneliti bersama-sama dengan para siswa (kelompok) mempersiapkan segala hal yang dibutuhkan dalam kerja kelompok. Selain itu peneliti membagi tugas dalam mengerjakan soal didalam kelompok agar mereka terbiasa bertanggung jawab dan disiplin terhadap tugas yang diberikan supaya mereka dapat berpikir secara kritis. Jika ada yang belum dimengerti untuk kemudian dimusyawarahkan secara bersam-sama. Di akhir sesi peneliti meminta perwakilan dari setiap kelompok untuk menyampaikan hasil diskusi kelompoknya di depan kelas, sedangkan siswa yang lain mendengarkan dan mengamati jawaban dari kelompok lain. Setelah kegiatan selsai peneliti bersama kelompok lain menanggapi hasil pekerjaan kelompok yang ditunjuk oleh peneliti.

\section{Peningkatan Keaktifan Belajar Akidah Akhlak pada Siswa Kelas V B melalui Model Pembelajaran Jigsaw}

Peningkatan keaktifan belajar siswa siklus I dalam penelitian ini menunjukan kriteria keaktifan belajar mencukupi yang dimana persentasi keaktifan belajar siswa 54\%. ${ }^{22}$ Meskipun pada pelaksanaan tindakan pada siklus I sudah cukup nampak, pelaksanaan tindakan pada siklus I masih terdapat beberapa hal kurang maksimal.Hal-hal tersebut diantaranya 1) kurangnya kesiapan belajar siswa dalam menerima materi, sehingga

\footnotetext{
${ }^{21}$ Penerapan Model Pembelajaran Jigsaw

${ }^{22}$ Hasil Penelitian Peningkatan Keaktivan Belajar Akidah Akhlak Melalui Metode Jigsaw
}

dalam kegiatan belajar mengajar berlangsung siswa-siswa kurang aktif dan terkesan bermain pada saat kegiatan belajar mengajar. 2) guru kurang memberikan bimbingan pada siswa saat mengerjakan soal pada LKS. 3) interaksi siswa dengan guru masih kurang. 4) ketika mengerjakan soal LKS siswa masih mengerkajakn soal secara mandiri. Dalam penelitian tindakan pada siklus I ini peneliti masih belum merasa puas dikarenakan masih terdapat beberapa kendala, yang dianggap dapat diatasi dengan rekomendasi yang telah direncanakan pada refleksi siklus I guna meprbaiki kendala-kendala yang dihadapi pada siklus I.

Pada siklus II, menunjukan keaktifan belajar siswa meningkat yang awalnya dimana pada siklus I hasil observasi aktivitas siswa persentasi keaktifan belajar siswa 54\%, dengan katagoti cukup nampak. Sesudah melakukan tindakan kelas dengan menggunakan model pembelajaran jigsaw kemudian pada siklus II meperoleh persentase kektifan belajar siswa 79\% dengan kriteria keaktifan belajar sangat nampak, terlihat sangat jelas pada siklus II mengalami peningkatan.

Dalam pelaksanaan tindakan disiklus II ini selain terjadi peningkatan keaktifan belajar, hasil refleksi siklus I yang dihadapi pada siklus I sudah mulai nampak hasilnya dengan rekomendasi yang telah direncanakan pada refleksi siklus I. Ketika proses belajar mengajar berlangsung siswa antusias dalam menerima materi dan mendengarkan penjelasan guru, siswa-siswa sudah mulai aktif dan tidak bermain-main ketika pembelajaran berlangsung, guru juga memberikan bimbingan kepada siwa-siswa ketika belajar kelompok untuk menjawab pertanyaanpertanyaan. Meskipum demikian, guru sudah mulai melakukan upaya untuk mengatasi hasil refleksi pada siklus I.

Berdasarkan hasil tindakan pada siklus II, kekatifan belajar siswa sudah tercapai/nampak dan kendala-kendala pada refleksi siklus I mulai teratasi pada pelaksanaan di siklus II. Dengan demikian siklus penelitian tindakan kelas ini dapat dihentikan.

\section{E. SIMPULAN DAN SARAN}

\section{1) Simpulan}

Berdasarkan hasil penelitian dan pembahasan yang sudah peneliti jelaskan, dapat disimpulkan bahwa dengan penerapan metode jigsaw dapat meningkatkan keaktifan belajar pada siswa kelas V B MI An-Najah Desa Sesela Kecamatan Gunungsari. Peningkatan keaktifan belajar akidah akhlak dalam penelitian ini dapat 
diperoleh melalui lembar hasil observasi Aktivitas siswa berdasarkan observasi aktivitas belajar siswa oleh peneliti pada pelaksanaan model pembelakaran jigsaw pada siklus I dan II, siswasiswa mulai tertarik dengan model pembelajaran jigsaw.selain itu siswa-siswa mulai memperhatikan guru saat menjelaskan materi.

\section{2) Saran}

Peningkatan keaktifan belajar siswa pada siklus I dalam penelitian ini menunjukan kriteria keaktifan belajar siswa yaitu cukup nampak dengan persentasi keaktifan belajar siswa 54\%. Selanjutnya pada siklus II setelah dilakukan perbaikan oleh peneliti terdapat peningkatan. Pada pelaksanaan siklus II memperoleh persentase keaktifan belajar siswa $79 \%$ dengan kriteria keaktifan belajar sangat nampak. Dengan demikian dapat diketahui bahwa dengan menerapkan model pembelajan jigsaw dapat meningkatkan keaktifan belajar siswa.

\section{DAFTAR RUJUKAN}

Al- Qur;an. 2015, Al- Qur;an Penerjemah. Depok: Penerbit SABIQ

Anwar Rosihon, 2014, Akidah Akhlak, Bandung : CV Pustaka Setia

Arikunto Suharsimi, 2012, Penelitian Tindakan Kelas,Jakarta: PT Bumi Askara

Aqib Zainal, 2010, Penelitian Tindakan Kelas,Bandung: CV Yrama Widya

Badar Ibnu Trianto, 2015, Mendesain Model Pembelajaran Inovatife, Progresif Dan Kontekstual,Jakarta: Pranada Media Group

Mappanyompa. 2019, Pengaruh Pendidikan Kemuhammadiyahan Terhadap Sikap Perilaku Siswa, Ibtida'iy Journal PGMI, 4 (1),17-29.

Hamdayana Jumanta, 2014, Model Dan Metode Pembelajaran Kreatif Dan Berkarakter, Bogor: Ghalia Indonesia

Iskandar, 2011, Penelitian Tindakan Kelas, Jakarta : Gaung Persada

Mudjiono, 2009, Belajar Dan Pembelajaran,Jakarta : Rineka Pustaka

Purwanto Ngalim, 2012, Teknik-Teknik Dan Evaluai Pengajaran, Bandung: PT Remaja Rosdakarya

SI dan SKL, 2006, Permendiknas,Jakarta : Sinar Grafika

Slameto, 2010, Belajar Dan Faktor-Faktor Yang Mempengaruhinya,Jakarta : PT Raneka Cipta

Sukarta, 2015, Kuliah Akhlak,Mataram: Lembaga Pengajian Dan Pengalaman Islam
Suprijiono Agus, 2016, Model- Model Pembelajaran, Yogyakarta : Pustaka Pelajar

Suprijiono Agus, 2011, Cooperative Learning Teori Dan Aplikasi Paikem, Yogyakarta : Pustaka Pelajar

Mappanyompa. (2020). Penggunaan Media Tiga Dimensi Dalam Meningkatkan Hasil Belajar Atematika Siswa, Ibtida'iy Journal PGMI, 4 (2), 104-110.

Susanto Ahmad, 2016, Teori Belajar Dan Pembelajaran Di Sekolah Dasar,Jakarta : Prenadamedia Group

Sukarta, 2015, Kuliah Akidah, Mataram: Lembaga Pengajian Dan Pengalaman Islam 